\title{
Studies on physico-chemical changes occurred during storage in Lassi prepared from cow milk blended with sapota pulp
}

\author{
K.B. SHINDE, R.R. SHELKE, P.A.KAHATE AND K.U. BIDWE
}

\begin{abstract}
Present investigation was conducted to study the physico-chemical changes occurred in Lassi prepared from cow milk blended with sapota pulp during storage at refrigeration temperature $\left(7 \pm 1^{\circ} \mathrm{C}\right)$. Fresh cow milk was standardized at 3.5 per cent fat and 8.5 per cent $\mathrm{SNF}$ then used for the investigation. Five treatments of sapota pulp blended lassi i. e. $\mathrm{T}_{1}, \mathrm{~T}_{2}, \mathrm{~T}_{3}, \mathrm{~T}_{4}$ and $\mathrm{T}_{5}$ with different levels of sapota pulp $(0,5,10,15$ and $20 \%)$ by weight of lassi added during preparation. The physico-chemical analysis was followed to observe the chemical changes occurred in lassi during storage and it was observed that moisture, fat and $\mathrm{pH}$ was decreased, while total solids, protein and acidity were increased.
\end{abstract}

KEY WORDS : Lassi, Sapota pulp, Chemical composition, Fat, Protein, Moisture, Total solid, Solids not fat, pH, Keeping quality

How To CITE THIS PAPER : Shinde, K.B., Shelke, R.R., Kahate, P.A. and Bidwe, K.U. (2015). Studies on physico-chemical changes occurred during storage in Lassi prepared from cow milk blended with sapota pulp. Res. J. Animal Hus. \& Dairy Sci., 6(2) :115-120.

Address for correspondence :

R.R. Shelke, Department of Animal Husbandry and Dairy Science, College of Agriculture, Dr. Panjabrao Deshmukh Krishi Vidyapeeth, AKOLA (M.S.) INDIA Email : rrspkv@gmail.com

Associated Authors' :

K.B. Shinde, P.A. Kahate and K.U. Bidwe, Department of Animal Husbandry and Dairy Science, College of Agriculture, Dr. Panjabrao Deshmukh Krishi Vidyapeeth, AKOLA (M.S.) INDIA 